\title{
Rapid Assessment of Amphibians at Milonchari Area in Bandarban District, Bangladesh
}

\author{
Faysal Ahmad ${ }^{1,3}$ and Ebtisamul Zannat Mim $^{2}$ \\ ${ }^{1}$ Department of Zoology, Jagannath University, Dhaka, Bangladesh (faysal.nature@gmail.com) \\ ${ }^{2}$ Department of Zoology, University of Dhaka, Dhaka, Bangladesh \\ ${ }^{3}$ World Vision International \\ Photographs by the senior author.
}

B angladesh is a global biodiversity hotspot in tropical Asia with a unique and diverse biota in a wide variety of poorly unexplored habitats. Situated at the junction of the Indo-Himalayan and Indo-Chinese Sub-regions (Stanford 1991), it has 25 recognized bioecological zones based on temperature, precipitation, soil quality, hydrological conditions, and the diversity of flora and fauna (Nishat et al. 2002). Over 1,600 animal species have been documented in Bangladesh, including 138 mammals, 566 birds, 167 reptiles, 49 amphibians, 253 freshwater fishes, 141 crustaceans, and 305 species of butterflies (IUCN Bangladesh 2015).

Forty-nine species of amphibians have been recorded in Bangladesh (Hasan et al. 2014). Two are listed by IUCN Bangladesh (2015) as Critically Endangered (CR), three as Endangered (EN), five as Vulnerable (VU), six as Near Threatened (NT), six as Data Deficient (DD), and the remaining 27 as species of Least Concern (LC).

Amphibians play vital roles in natural ecosystems, often functioning to control biological pests (e.g., Matthews et al. 2002; Whiles et al. 2006). However, location-specific information on amphibian diversity and habitat preferences in Bangladesh is insufficient. Herein we present the results of a rapid assessment of amphibian diversity and habitat preferences in the Milonchari Area of the Bandarban District in Bangladesh. This area is covered by highly diverse, mostly intact, and poorly explored forests that extend into Myanmar and northeastern India. Rapid Assessments are accelerated, targeted, and flexible studies of biodiversity that focus on species related to specific vegetation types or topographical characteristics (Sayre et al. 2000).

At 1800-0100 h over three nights from 24-26 May 2017, we conducted visual-encounter surveys in the Milonchari Area of the Bandarban District $\left(21^{\circ} 48^{\prime} \mathrm{N}\right.$, $\left.92^{\circ} 24^{\prime} \mathrm{E}\right)$ using headlamps and flashlights while following a transect and emphasizing amphibian habitats that included small permanent and intermittent pools and streams and areas with dense vegetation. We captured at least one indi- vidual of every species encountered and photographed them in daylight. We subsequently released most of them but

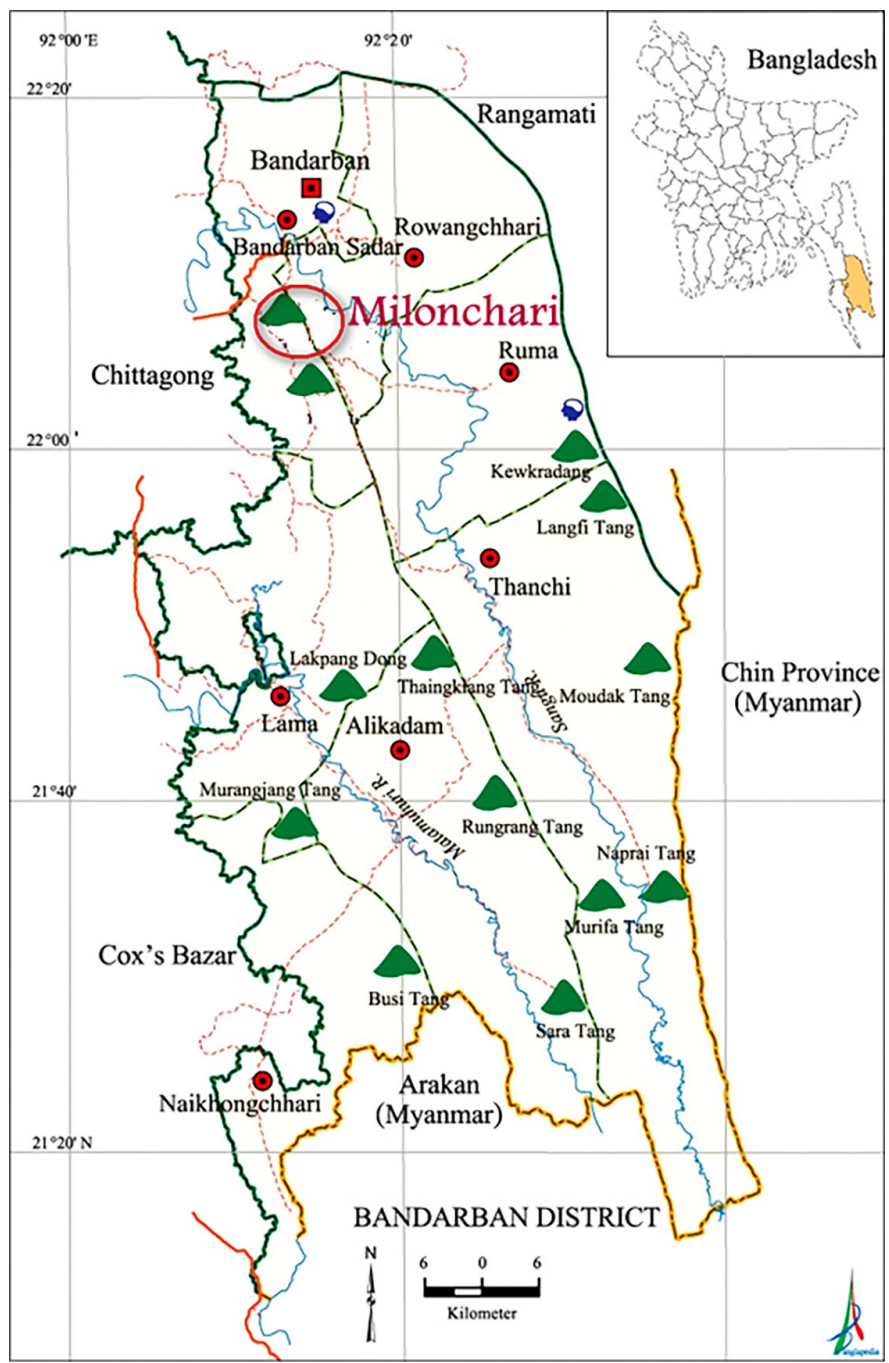

Fig. 1. Map of the Bandarban District showing the location of the Milonchari Area, where we conducted a rapid assessment of amphibian diversity and habitat preferences (adapted from Banglapedia: The National Encyclopedia of Bangladesh). 

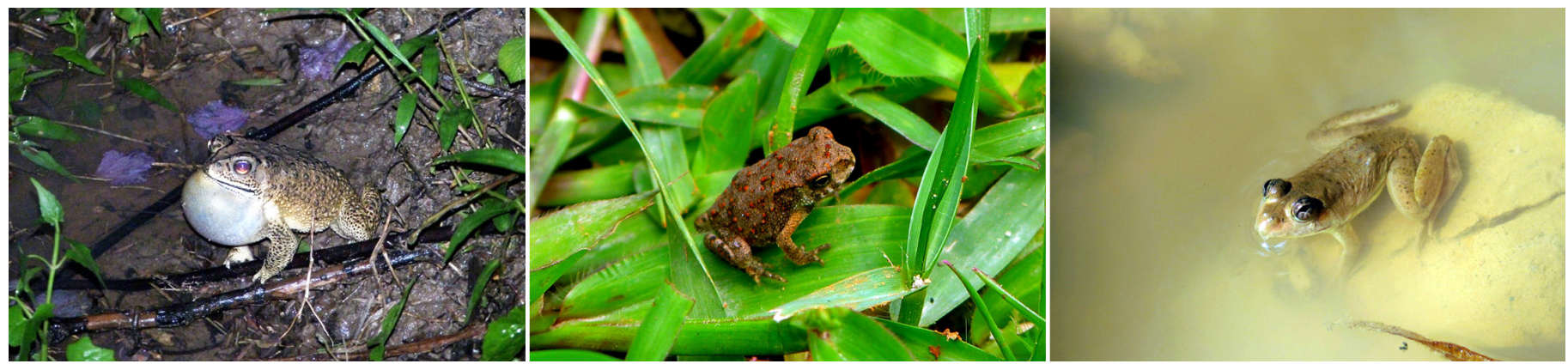

Fig. 2. Asian Common Toad (Duttaphrynus melanostictus; left), Marbled Toad (Duttaphrynus stomaticus; center), and Skipper Frog (Euphlyctis cyanophlyctis; right).

preserved a few cryptic specimens in $60 \%$ ethanol for further examination. With the exception of frogs in the genus Fejervarya, which are cryptic and require genetic analyses to distinguish, we identified frogs to species with the assistance of Drs. Kaushik Deuti (Zoological Survey of India), Abhijit Das (Wildlife Institute of India), and Mohammad Abdul Wahed Chowdhury (University of Chittagong, Bangladesh).

We found 17 of the 49 species of anurans known from Bangladesh, one of which is Endangered, three Near Threatened, and 13 of Least Concern (Table 1). In the fol- lowing species accounts, $\mathrm{AOO}=$ Area of Occupancy, $\mathrm{EOO}=$ Extent of Occurrence.

\section{Bufonidae}

Duttaphrynus melanostictus (Asian Common Toad). N > 80 (breeding chorus). $\mathrm{EOO}=222,509 \mathrm{~km}^{2}$ and $\mathrm{AOO}=132,741$ $\mathrm{km}^{2}$ (Rahman 2015a). Globally, this species is found in Bangladesh, Cambodia, China, India, Indonesia, Lao PDR, Malaysia, Myanmar, Nepal, Papua New Guinea, Pakistan, Singapore, Sri Lanka, Thailand, and Vietnam (van Dijk et

Table 1. List of species found during a rapid assessment of amphibian diversity and habitat preferences in the Milonchari Area of the Bandarban District in Bangladesh with national and global conservation status. Some species listed herein as Fejervarya sp. might be more accurately assigned to the genus Minervarya (Sanchez et al. 2018; Köhler et al. 2019). Feihyla vittata was until recently (Li et al. 2013) placed in the genus Chiromantis (as C. vittatus). Theloderma andersoni has recently been considered to be in the genus Philautus, but the taxonomy is not fully resolved (e.g., Hou et al. 2017).

\begin{tabular}{llll}
\hline & Species & Bangladesh & Global \\
\hline Bufonidae & & & \\
\hline & Duttaphrynus melanostictus & LC & LC \\
\hline Dicroglossidae & Duttaphrynus stomaticus & LC & LC \\
\hline & Euphlyctis cyanophlyctis & LC & LC \\
\hline & Fejervarya spp. & LC & LC \\
\hline Hoplobatrachus tigerinus & LC \\
\hline Megophryidae & Ingerana borealis & NT & VU \\
\hline Microhylidae & Occidozyga lima & LC & LC \\
\hline & Megophrys parva & NT & LC \\
\hline Ranidae & Kaloula pulchra & NT & LC \\
\hline & Microhyla berdmorei & LC \\
\hline Rhacophoridae & Microhyla ornata & LC & LC \\
\hline & Clinotarsus alticola & LC \\
\hline & Hylarana leptoglossa & LC & LC \\
\hline & Feihyla vittata & LC & LC \\
\hline & Polypedates leucomystax & LC & LC \\
\hline & Rhacophorus bipunctatus & LC & LC \\
\hline Theloderma andersoni & EN & LC
\end{tabular}



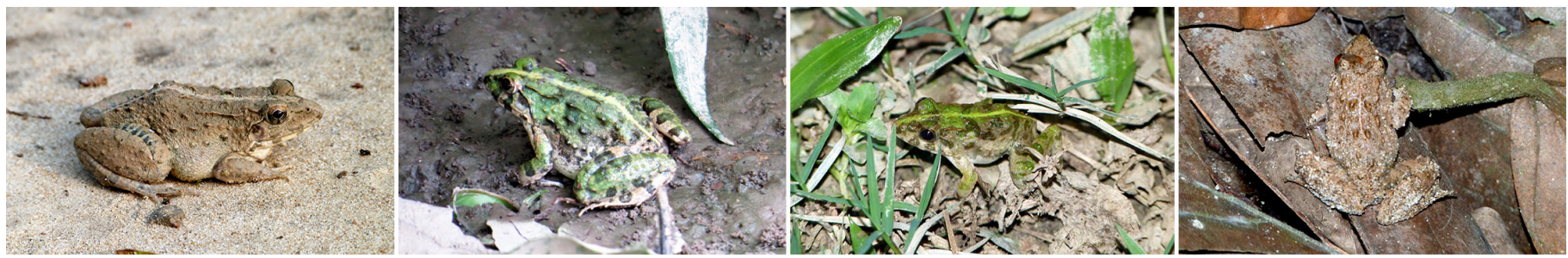

Fig. 3. Four Cricket Frogs (Fejervarya spp.) not assigned to species. Note that some species listed herein as Fejervarya sp. might be more accurately assigned to the genus Minervarya (Sanchez et al. 2018; Köhler et al. 2019).

al. 2004a). This species is the most frequently encountered amphibian in Bangladesh, where it occurs in a variety of habitats, including the hill country and all terrestrial forest ecosystems, throughout the mainland into coastal areas and onto offshore islands (M.A.R. Khan 1982, 1987, 2015; M.M.H. Khan 2008; Pratihar et al. 2014; Rahman 2015a).

Duttaphrynus stomaticus (Marbled Toad). N > 30. EOO $=82,486 \mathrm{~km}^{2}$ and $\mathrm{AOO}=17,528 \mathrm{~km}^{2}$ (Rahman 2015b). Globally, this species is found in Afghanistan, Bangladesh, India, Iran, Nepal, Oman, and Pakistan (Stöck et al. 2009). In Bangladesh, these toads are distributed through central and southwestern parts of the country, particularly the chars of the Ganges-Brahmaputra-Meghna River Systems; the species also has been recorded from Rajshahi, Rangpur, and Sundarbans (A.B.M.S. Alam et al. 2012; Pratihar et al. 2014; Hasan et al. 2014; M.A.R. Khan 2015; Rahman 2015b).

\section{Dicroglossidae}

Euphlyctis cyanophlyctis (Skipper Frog or Skittering Frog). $\mathrm{N}>15 . \mathrm{EOO}=222,509 \mathrm{~km}^{2}$ and $\mathrm{AOO}=139,772 \mathrm{~km}^{2}$ (Chowdhury 2015a). Globally, this species is found in Afghanistan, Bangladesh, Bhutan, India, Iran, Myanmar, Nepal, Pakistan, Sri Lanka, and Vietnam (M.S. Khan et al. 2009). In Bangladesh, this species has the widest distribution of all anurans, ranging from coastal areas into the hilly terrain of the Bandarban District (M.A.R. Khan 1987, 2015; M.S. Alam et al. 2008; Mahony and Reza 2008; Mahony et al. 2009; Chowdhury 2015a).

Fejervarya spp. (Cricket Frogs). N > 200. These species are widely distributed throughout the Indian Subcontinent (IUCN Bangladesh 2015). Note that some species listed herein as Fejervarya sp. might be more accurately assigned to the genus Minervarya (Sanchez et al. 2018; Köhler et al. 2019).

Hoplobatrachus tigerinus (Indian Bullfrog). N > 60. EOO $=222,509 \mathrm{~km}^{2}$ and $\mathrm{AOO}=139,772 \mathrm{~km}^{2}$ (Sultana 2015). Globally, this frog is found in Afghanistan, Bangladesh, India, Myanmar, Nepal, and Pakistan (Padhye et al. 2008). In Bangladesh, this species probably is the most widely distributed of the larger anuran species (M.A.R. Khan 1982, 1987, 2015; Hasan et al. 2014; Sultana 2015).

Ingerana borealis (Northern Frog or Boreal Floating Frog). $\mathrm{N}>120 . \mathrm{EOO}=41,602 \mathrm{~km}^{2}$ and $\mathrm{AOO}=10,626 \mathrm{~km}^{2}$ (Hasan 2015a). Globally, this species is found in Bangladesh, Bhutan, and India (Lau et al. 2004a). In Bangladesh, this species is found in the mixed evergreen forests in the hilly areas of the northeastern and southeastern parts of the country (Hasan et al. 2014; Sarker and Lovlu 2014; Hasan 2015a) and is particularly abundant in and around Madhabkunda (M.A.R. Khan 2015).

Occidozyga lima (Puddle Frog). $\mathrm{N}>5 . \mathrm{EOO}=41,602 \mathrm{~km}^{2}$ and $\mathrm{AOO}=10,626 \mathrm{~km}^{2}$ (Hasan 2015c). Globally, this species occurs in Bangladesh, Cambodia, China, India, Indonesia, Lao PDR, Malaysia, Myanmar, Thailand, and Vietnam (van Dijk et al. 2004b). In Bangladesh, these frogs inhabit mixed evergreen forests and surrounding areas in the southeastern part of the country (Hasan et al. 2014; Hasan 2015c).

\section{Megophryidae}

Megophrys parva (Concave-crowned Horned Frog, Mountain Horned Frog). $\mathrm{N}>150 . \mathrm{EOO}=13,320 \mathrm{~km}^{2}$ and $\mathrm{AOO}=$ $2,722 \mathrm{~km}^{2}$ (Chakma 2015a). Globally, this species is found in Bangladesh, Bhutan, China, India, Lao PDR, Myanmar,
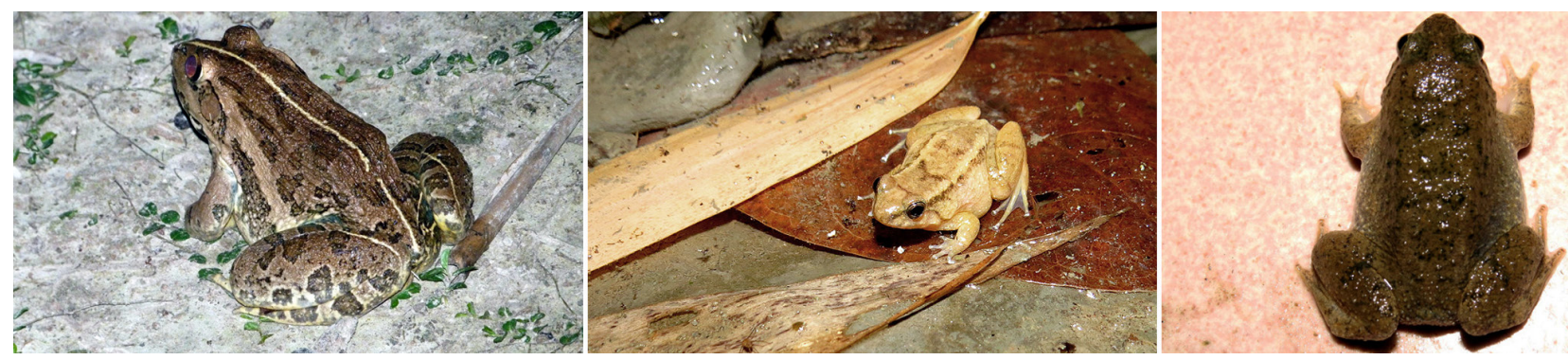

Fig. 4. Indian Bullfrog (Hoplobatrachus tigerinus; left), Northern Frog (Ingerana borealis; center), and Puddle Frog (Occidozyga lima; right). 


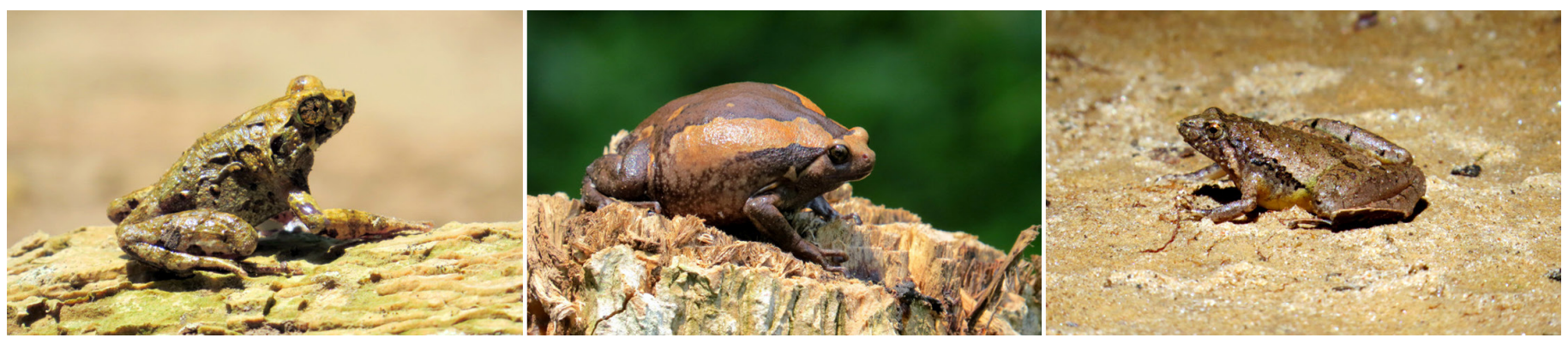

Fig. 5. Concave-crowned Horned Frog (Megophrys parva; left), Asian Painted Frog (Kaloula pulchra; center), and Berdmore's Narrow-mouthed Frog (Microhyla berdmorei; right).

Nepal, Thailand, and Vietnam (van Dijk et al. 2004c). In Bangladesh, this species has been reported from the Chittagong Hill Tracts, Chittagong, and Greater Sylhet; it is particularly abundant in the Madhabkunda Eco-park (Chakma 2015a; M.A.R. Khan 2015).

\section{Microhylidae}

Kaloula pulchra (Painted Bullfrog or Asian Painted Frog). $\mathrm{N}>50 . \mathrm{EOO}=41,602 \mathrm{~km}^{2}$ and $\mathrm{AOO}=10,623 \mathrm{~km}^{2}$ (Ahsan 2015). Globally, this species is found in Bangladesh, Cambodia, China, India, Indonesia, Lao PDR, Malaysia, Myanmar, Nepal, Singapore, Thailand, and Vietnam (Kuangyang et al. 2004). In Bangladesh, it is found in and around mixed-evergreen forests in the eastern, northeastern, and southeastern parts of the country and near human habitations in the hill districts (M.A.R. Khan 1982, 1987, 2015; Hasan et al. 2014; Ahsan 2015).

Microhyla berdmorei (Berdmore's Narrow-mouthed Frog). $\mathrm{N}>20 . \mathrm{EOO}=93,049 \mathrm{~km}^{2}$ and $\mathrm{AOO}=36,293$ $\mathrm{km}^{2}$ (Chowdhury 2015b). Globally, this species is found in Bangladesh, Cambodia, China, India, Indonesia, Malaysia, Myanmar, Thailand, Lao PDR, and Vietnam (van Dijk et al. 2004d). In Bangladesh, these frogs are found in the deciduous and mixed evergreen forests of the central, eastern, northeastern, and southeastern parts of the country (Asmat et al. 2003; Hasan et al. 2014; Chowdhury 2015b; M.A.R. Khan 2015).

Microhyla ornata (Ornate Narrow-mouthed Frog, Ant Frog). $\mathrm{N}>100$ (breeding chorus). EOO $=222,509 \mathrm{~km}^{2}$ and AOO $=136,929 \mathrm{~km}^{2}$ (Hasan 2015b). Globally, this species is found in Bangladesh, India, Bhutan, Nepal, Pakistan, and
Sri Lanka (Dutta et al. 2008). In Bangladesh, these frogs are widely distributed and occur in a variety of habitats (Hasan et al. 2014; Hasan 2015b; M.A.R. Khan 2015).

\section{Ranidae}

Clinotarsus alticola (Point-nosed Frog). $\mathrm{N}>25$. EOO = $41,602 \mathrm{~km}^{2}$ and $\mathrm{AOO}=10,624 \mathrm{~km}^{2}$ (Rahman 2015c). Globally, this species is found in Bangladesh, India, Myanmar, and Thailand (van Dijk et al. 2004e). In Bangladesh, this species is found in the northeastern and southeastern parts of the country (M.M.H. Khan 2008; Mahony et al. 2009; M.A.R. Khan 2015; Rahman 2015c).

Hylarana leptoglossa (Cope's Assam Frog). $\mathrm{N}>8 . \mathrm{EOO}=$ $55,093 \mathrm{~km}^{2}$ and $\mathrm{AOO}=1,626 \mathrm{~km}^{2}$ (Ahmed. 2015). Globally, this frog is found in Bangladesh, India, Myanmar, and Thailand (IUCN SSC Amphibian Specialist Group 2016). In Bangladesh, these frogs are widely distributed throughout the country, where they appear to be rather partial to deciduous and mixed evergreen forests, as well as other well vegetated habitats (Romer 1949; Asmat et al. 2003; Hasan et al. 2014; Ahmed. 2015; M.A.R. Khan 2015).

\section{Rhacophoridae}

Feihyla vittata (Striped Asian Treefrog). N > 10. EOO = 41,602 $\mathrm{km}^{2}$ and $\mathrm{AOO}=10,626 \mathrm{~km}^{2}$ (Hasan 2015d). Globally, these frogs are known to occur in Bangladesh, Cambodia, China, India, Lao PDR, Myanmar, Thailand, and Vietnam (Lau et al. 2004b). In Bangladesh, this species occupies mixed evergreen forests and surrounding areas in Chittagong and Sylhet Divisions (Hasan et al. 2014; Hasan 2015d).
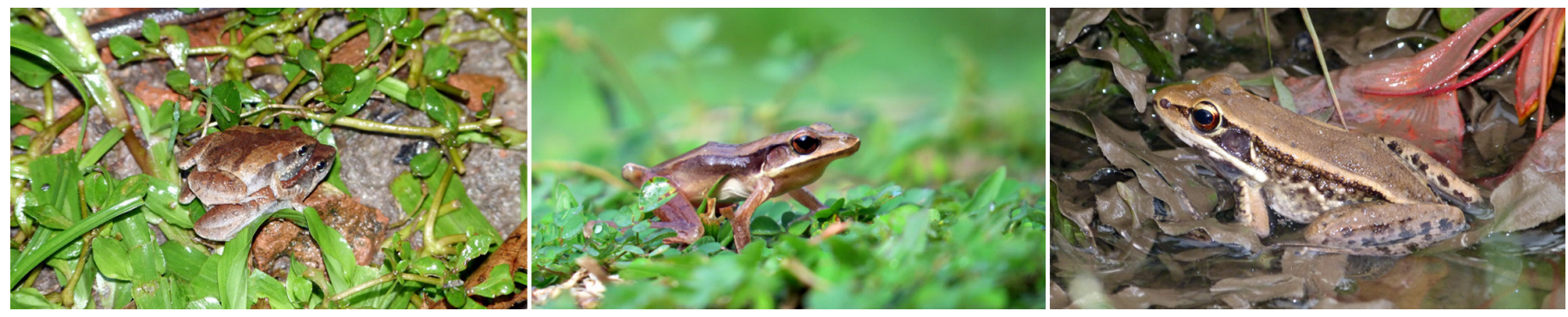

Fig. 6. Ornate Narrow-mouthed Frog (Microhyla ornata; left), Point-nosed Frog (Clinotarsus alticola; center), and Cope’s Assam Frog (Hylarana leptoglossa; right). 

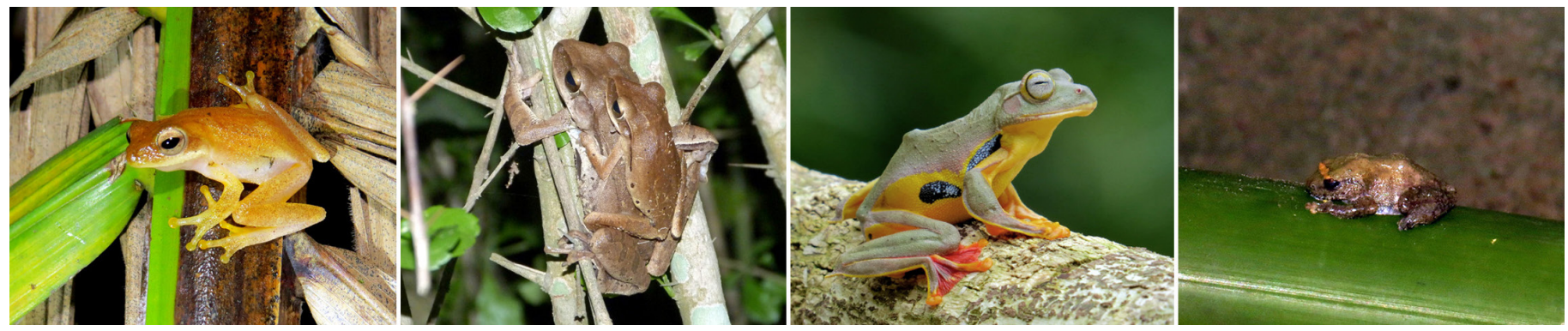

Fig. 7. Striped Asian Treefrog (Feihyla vittata; left), Common Asian Treefrog (Polypedates leucomystax; center left), Twin-spotted Treefrog (Rhacophorus bipunctatus; center right), and Anderson's Bush Frog (Theloderma andersoni; right).

Polypedates leucomystax (Common Asian Treefrog). $\mathrm{N}>$ 100 (breeding chorus). $\mathrm{EOO}=221,137 \mathrm{~km}^{2}$ and $\mathrm{AOO}=$ $136,929 \mathrm{~km}^{2}$ (Hasan 2015e). Globally, this species is found in Bangladesh, Brunei Darussalam, Cambodia, China, India, Indonesia, Lao PDR, Malaysia, Myanmar, Nepal, the Philippines, Singapore, Thailand, Vietnam, and Japan (Diesmos et al. 2004). In Bangladesh, these frogs are widely distributed throughout the country, ranging from coastal areas to the hilltops (M.A.R. Khan 1982, 1987, 2015; Hasan et al. 2014; Hasan 2015e).

Rhacophorus bipunctatus (Twin-spotted Treefrog). N > 20. $\mathrm{EOO}=35,483 \mathrm{~km}^{2}$ and $\mathrm{AOO}=10,549 \mathrm{~km}^{2}$ (Chakma 2015b). Globally, this species is found in Bangladesh, China, India, Malaysia, Myanmar, and Thailand (Ohler et al. 2008). In Bangladesh, these frogs occur in mixed evergreen forests, including secondary forests, in the northeastern and southeastern parts of the country (Ali Reza and Mukul 2009; Chakma 2015b; M.A.R. Khan 2015).

Theloderma andersoni (Anderson's Bush Frog, Anderson's Bubble-nest Frog). $\mathrm{N}=1 . \mathrm{EOO}=312 \mathrm{~km}^{2}$ and $\mathrm{AOO}=95$ $\mathrm{km}^{2}$ (M.M.H. Khan 2015). Globally, this species is found in Bangladesh, China, India, and Myanmar (van Dijk et al. 2004f). In Bangladesh, these frogs occur in and around Kaptai National Park in the Rangamati District (M.A.R. Khan 2012); although not found elsewhere, they likely occur in other suitable habitats in the southeastern part of the country (M.M.H. Khan 2015).

\section{Acknowledgements}

We are grateful to our parents and teachers who have always supported our work. We also thank the hillside resort authority in Bandarban, where we stayed, for providing support for the amphibian assessment. We extend our sincere thanks to Sofia Ahmed, Salsabil Rumpa, and Nasif Khan from Independent University, Bangladesh and Ashik Rahman from North South University, Bangladesh for their support during the field days for amphibian assessment. Finally, we thank the scientists who helped us with species identification. Finally, we thank the scientists who helped us with species identification and our special friend Pungky Nanda Pratama from Indonesia for his inspiration.

\section{Literature Cited}

Ahmed, A. 2015. Hylarana leptoglossa, p. 259. In: IUCN Bangladesh, Red List of Bangladesh Volume 4: Reptiles and Amphibians. IUCN (International Union for Conservation of Nature), Bangladesh Country Office, Dhaka, Bangladesh.

Ahsan, M.F. 2015. Kaloula pulchra, p. 234. In: IUCN Bangladesh, Red List of Bangladesh Volume 4: Reptiles and Amphibians. IUCN (International Union for Conservation of Nature), Bangladesh Country Office, Dhaka, Bangladesh.

Alam, M.S., T. Igawa, M.M.R. Khan, M.M. Islam, M. Kuramoto, M. Matsui, A. Kurabayashi, and M. Sumida. 2008. Genetic divergence and evolutionary relationships in six species of genera Hoplobatrachus and Euphlyctis (Amphibia: Anura) from Bangladesh and other Asian countries revealed by mitochondrial gene sequences. Molecular Phylogenetics and Evolution 48: 515-527.

Alam, A.B.M.S., M.S.M. Chowdhury, and I. Sobhan. 2012. Biodiversity of Tanguar Haor - A Ramsar Site of Bangladesh, Volume I: Wildlife. IUCN-Bangladesh, Dhaka, Bangladesh.

Asmat, G.S.M., Q. Banu, M.A. Islam, M.F. Ahsan, and S. Chakma. 2003. Amphibian fauna from Chittagong and Chittagong Hill-tracts, Bangladesh. University Journal of Zoology, Rajshahi University 22: 141-143.

Chakma, S. 2015a. Xenophrys parva, p. 233. In: IUCN Bangladesh, Red List of Bangladesh Volume 4: Reptiles and Amphibians. IUCN (International Union for Conservation of Nature), Bangladesh Country Office, Dhaka, Bangladesh.

Chakma, S. 2015b. Rhacophorus bipunctatus, p. 266. In: IUCN Bangladesh, Red List of Bangladesh Volume 4: Reptiles and Amphibians. IUCN (International Union for Conservation of Nature), Bangladesh Country Office, Dhaka, Bangladesh.

Chowdhury, M.A.W. 2015a. Euphlyctis cyanophlyctis, p. 246. In: IUCN Bangladesh, Red List of Bangladesh Volume 4: Reptiles and Amphibians. IUCN (International Union for Conservation of Nature), Bangladesh Country Office, Dhaka, Bangladesh.

Chowdhury, M.A.W. 2015b. Microhyla berdmorei, p. 255. In: IUCN Bangladesh, Red List of Bangladesh Volume 4: Reptiles and Amphibians. IUCN (International Union for Conservation of Nature), Bangladesh Country Office, Dhaka, Bangladesh.

Diesmos, A.C., A. Alcala, R. Brown, L.E. Afuang, G. Gee, J. Sukumaran, N. Yaakob, L. Ming, Y. Chuaynkern, K. Thirakhupt, I. Das, D. Iskandar, Mumpuni, R.F. Inger, R. Stuebing, P. Yambun, and M. Lakim. 2004. Polypedates leucomystax (errata version published in 2016). The IUCN Red List of Threatened Species 2004: e.T58953A86477485. <https://dx.doi. org/10.2305/IUCN.UK.2004.RLTS.T58953A11861409.en>.

Dutta, S., T. Kumar Shrestha, K. Manamendra-Arachchi, M.S. Khan, and D. Roy. 2008. Microhyla ornata. The IUCN Red List of Threatened Species 2008: e.T57886A11686884. <https://dx.doi.org/10.2305/IUCN.UK.2008.RLTS. T57886A11686884.en>.

Hasan, M.K. 2015a. Ingerana borealis, p. 237. In: IUCN Bangladesh, Red List of Bangladesh Volume 4: Reptiles and Amphibians. IUCN (International Union for Conservation of Nature), Bangladesh Country Office, Dhaka, Bangladesh.

Hasan, M.K. 2015b. Microhyla ornata, p. 244. In: IUCN Bangladesh, Red List of Bangladesh Volume 4: Reptiles and Amphibians. IUCN (International Union for Conservation of Nature), Bangladesh Country Office, Dhaka, Bangladesh.

Hasan, M.K. 2015c. Occidozyga lima, p. 256. In: IUCN Bangladesh, Red List of Bangladesh Volume 4: Reptiles and Amphibians. IUCN (International Union for Conservation of Nature), Bangladesh Country Office, Dhaka, Bangladesh.

Hasan, M.K. 2015d. Chiromantis vittatus, p. 263. In: IUCN Bangladesh, Red List of Bangladesh Volume 4: Reptiles and Amphibians. IUCN (International Union 
for Conservation of Nature), Bangladesh Country Office, Dhaka, Bangladesh.

Hasan, M.K. 2015e. Polypedates leucomystax, p. 264. In: IUCN Bangladesh, Red List of Bangladesh Volume 4: Reptiles and Amphibians. IUCN (International Union for Conservation of Nature), Bangladesh Country Office, Dhaka, Bangladesh.

Hasan, M.K., M.M.H. Khan, and M.M. Feeroz. 2014. Amphibians and Reptiles of Bangladesh - A Field Guide. Arannayk Fundation, Dhaka, Bangladesh.

Hou, M., G.-H. Yu, H.-M. Chen, C.-L. Liao, L. Zhang, J. Chen, P.-P. Li, and N.L. Orlov. 2017. The taxonomic status and distribution range of six Theloderma species (Anura: Rhacophoridae) with a new record in China. Russian Journal of Herpetology 24: 99-127.

IUCN Bangladesh. 2015. Red List of Bangladesh Volume 4: Reptiles and Amphibians. IUCN (International Union for Conservation of Nature), Bangladesh Country Office, Dhaka, Bangladesh.

Khan, M.A.R. 1982. Wildlife of Bangladesh: A Checklist. The University of Dhaka, Dhaka, Bangladesh.

Khan, M.A.R. 1987. Bangladesher Bonnyoprani Vol 1. Uvochor O Shorishrip (in Bengali). (Wildlife of Bangladesh vol. 1. Amphibians and Reptiles). Bangla Academy, Dhaka.P.

Khan, M.A.R. 2015.Wildlife of Bangladesh: Checklist-cum-guide. M.J. Alam, Chayabithi, Dhaka, Bangladesh.

Khan, M.M.H. 2008. Protected Areas of Bangladesh-A Guide to Wildlife. Nishorgo Support Program, Bangladesh Forest Department, Dhaka, Bangladesh.

Khan, M.M.H. 2015. Philautus andersoni, p. 224. In: IUCN Bangladesh, Red List of Bangladesh Volume 4: Reptiles and Amphibians. IUCN (International Union for Conservation of Nature), Bangladesh Country Office, Dhaka, Bangladesh.

Khan, M.S., T. Papenfuss, S. Anderson, N. Rastegar-Pouyani, S. Kuzmin, S. Dutta, K. Manamendra-Arachchi, and M. Sharifi. 2009. Euphlyctis cyanophlyctis (errata version published in 2016). The IUCN Red List of Threatened Species 2009: e.T58260A86626211. <https://dx.doi.org/10.2305/IUCN.UK.2009. RLTS.T58260A11745753.en>.

Köhler, G., L. Mogk, K.P.P. Khaing, and N.L. Than. 2019. The genera Fejervarya and Minervarya in Myanmar: Description of a new species, new country records, and taxonomic notes (Amphibia, Anura, Dicroglossidae). Vertebrate Zoology 69: 183-226.

Kuangyang, L., Y. Zhigang, S. Haitao, G. Baorong, P.P. van Dijk, D. Iskandar, R.F. Inger, S. Dutta, S. Sengupta, S. Uddin Sarker, and G.S.M. Asmat. 2009. Kaloula pulchra (errata version published in 2016). The IUCN Red List of Threatened Species 2004: e.T57855A86163405. <https://dx.doi.org/10.2305/ IUCN.UK.2004.RLTS.T57855A11694615.en>.

Lau, M.W.N., S. Dutta, A. Ohler, S. Bordoloi, and G.S.M. Asmat. 2004a. Ingerana borealis. The IUCN Red List of Threatened Species 2004: e.T58407A11774694. https://dx.doi.org/10.2305/IUCN.UK.2004.RLTS.T58407A11774694.en.

Lau, M.W.N., C. Wenhao, G. Baorong, Y. Datong, P.P. van Dijk, N. Quang Truong, S. Dutta, S. Bordoloi, and S. Sengupta. 2004b. Feihyla vittata. The IUCN Red List of Threatened Species 2004: e.T58797A11831781. <https:// dx.doi.org/10.2305/IUCN.UK.2004.RLTS.T58797A11831781.en>.

Li, J.-T., Y. Li, S. Klaus, D.-Q. Rao, D.M. Hillis, and Y.-P. Zhang. 2013. Diversification of rhacophorid frogs provides evidence for accelerated faunal exchange between India and Eurasia during the Oligocene. Proceedings of the National Academy of Sciences of the United States of America 110: 3441-3446.

Mahony, S. and A.H.M.A. Reza. 2008. A herpetofaunal collection from the Chittagong Hill Tracts, Bangladesh, with two new species record for the country. Hamadryad 32: 34-45.

Mahony, S., M.K. Hasan, M.M. Kabir, M. Ahmed, and M.K. Hossain. 2009. A catalogue of amphibians and reptiles in the collection of Jahangirnagar University, Dhaka, Bangladesh. Hamadryad 34: 80-94.

Matthews, K.R., R.A. Knapp, and K.L. Pope. 2002. Garter snake distributions in high-elevation aquatic ecosystems: is there a link with declining amphibian populations and non-native trout introductions? Journal of Herpetology 36: 16-22.

Nishat, A., S.M.I. Huq, S.P. Barua, A.H.M.A. Reza, A.R. Khan, and A.S. Moniruzzaman. 2002. Bio-ecological Zones of Bangladesh. IUCN Bangladesh Country Office, Dhaka, Bangladesh.

Ohler, A., P.P. van Dijk, G. Wogan, F. Liang, S. Dutta, S. Bordoloi, and D. Roy. 2008. Rhacophorus bipunctatus. The IUCN Red List of Threatened Species 2008: e.T58981A11853687. <https://dx.doi.org/10.2305/IUCN.UK.2008. RLTS.T58981A11853687.en>.

Padhye, A., K. Manamendra-Arachchi, A. de Silva, S.K. Dutta, T.K. Shrestha, S. Bordoloi, T. Papenfuss, S. Anderson, S. Kuzmin, M.S. Khan, and R. Nussbaum. 2008. Hoplobatrachus tigerinus. The IUCN Red List of Threatened
Species 2008: e.T58301A11760496. <https://dx.doi.org/10.2305/IUCN. UK.2008.RLTS.T58301A11760496.en>.

Pratihar, S., B.C. Patra, M.A.R. Sarker, and D.J.S. Samarasinghe. 2014. Duttaphrynus in India, Bangladesh and Sri Lanka. Indian Forester 140(10): 1035-1037.

Rahman, S.C. 2015a. Duttaphrynus melanostictus, p. 240. In: IUCN Bangladesh, Red List of Bangladesh Volume 4: Reptiles and Amphibians. IUCN (International Union for Conservation of Nature), Bangladesh Country Office, Dhaka, Bangladesh.

Rahman, S.C. 2015b. Duttaphrynus stomaticus, p. 241. In: IUCN Bangladesh, Red List of Bangladesh Volume 4: Reptiles and Amphibians. IUCN (International Union for Conservation of Nature), Bangladesh Country Office, Dhaka, Bangladesh.

Rahman, S.C. 2015c. Clinotarsus alticola, p. 257. In: IUCN Bangladesh, Red List of Bangladesh Volume 4: Reptiles and Amphibians. IUCN (International Union for Conservation of Nature), Bangladesh Country Office, Dhaka, Bangladesh.

Ali Reza, A.H.M. and S.A. Mukul. 2009. Geographic distribution: Rhacophorus bipunctatus (Twin-spotted Tree Frog). Herpetological Review 40: 447.

Romer, J.D. 1949. Herpetological observations in Assam and Bengal. 1944. Journal of the Bombay Natural History Society 48: 374-376.

Sanchez, E., S.D. Biju, M.M. Islam, M.K. Hasan, A. Ohler, M. Vences, and A. Kurabayashi. 2018. Phylogeny and classification of fejervaryan frogs (Anura: Dicroglossidae). Salamandra 54: 109-116.

Sarker, M.A.R. and A.H. Lovlu. 2014. Geographic distribution. Occidozyga borealis (Northern Frog). Herpetological Review 45: 655.

Sayre, R., E. Roca, G. Sedaghatkish, B. Young, S. Keel, R.L. Roca, and S. Sheppard. 2000. Nature in Focus: Rapid Ecological Assessment. Island Press, Washington DC.

Stanford, C.B. 1991. The capped langur in Bangladesh: Behavioural Ecology and Reproductive Tactics. Vol. 26. Karger Publishers, Basel, Switzerland.

Stöck, M., M.S. Khan, T. Papenfuss, S. Anderson, S. Kuzmin, N. RastegarPouyani, S. Dutta, A. Ohler, S. Sengupta, K. Manamendra-Arachchi, A. de Silva, S. Anderson, and M. Sharifi. 2009. Duttaphrynus stomaticus. The IUCN Red List of Threatened Species 2009: e.T54768A11201081. <https://dx.doi. org/10.2305/IUCN.UK.2009.RLTS.T54768A11201081.en>.

Sultana, R. 2015. Hoplobatrachus tigerinus, p. 254. In: IUCN Bangladesh, Red List of Bangladesh Volume 4: Reptiles and Amphibians. IUCN (International Union for Conservation of Nature), Bangladesh Country Office, Dhaka, Bangladesh.

van Dijk, P.P., D. Iskandar, M.W.N. Lau, G. Huiqing, G. Baorong, L. Kuangyang, C. Wenhao, Y. Zhigang, B. Chan, S. Dutta, R.F. Inger, K. ManamendraArachchi, and M.S. Khan. 2004a. Duttaphrynus melanostictus (errata version published in 2016). The IUCN Red List of Threatened Species 2004: e.T54707A86445591. <https://dx.doi.org/10.2305/IUCN.UK.2004.RLTS. T54707A11188511.en>.

van Dijk, P.P., D. Iskandar, M.W.N. Lau, Z. Ermi, G. Baorong, S. Haitao, S. Dutta, S. Sengupta, and S. Uddin Sarker. 2004b. Occidozyga lima (errata version published in 2016). The IUCN Red List of Threatened Species 2004: e.T58411A86626569. <https://dx.doi.org/10.2305/IUCN.UK.2004.RLTS. T58411A11775632.en>.

van Dijk, P.P., B. Stuart, Y. Datong, W. Guanfu, S. Dutta, S. Bordoloi, T. Kumar Shrestha, S. Sengupta, and G.S.M. Asmat. 2004c. Megophrys parva. The IUCN Red List of Threatened Species 2004: e.T57651A1 1669946. <https:// dx.doi.org/10.2305/IUCN.UK.2004.RLTS.T57651A11669946.en>.

van Dijk, P.P., R. Inger, D. Iskandar, Y. Datong, A. Ohler, L. Shunqing, S. Dutta, S. Bordoloi, S. Sengupta, and G.S.M. Asmat. 2004d. Microhyla berdmorei (errata version published in 2018). The IUCN Red List of Threatened Species 2004: e.T57876A136565297. <https://dx.doi.org/10.2305/IUCN.UK.2004. RLTS.T57876A11696719.en>.

van Dijk, P.P., A. Ohler, S. Dutta, S. Bordoloi, S. Uddin Sarker, M. Mohan Borah. 2004e. Clinotarsus alticola. The IUCN Red List of Threatened Species 2004: e.T58540A11798892. <https://dx.doi.org/10.2305/IUCN.UK.2004.RLTS. T58540A11798892.en>.

van Dijk, P.P., G. Wogan, S. Dutta, A. Ohler, and S. Sengupta. $2004 \mathrm{f}$. Theloderma andersoni. The IUCN Red List of Threatened Species 2004: e.T58815A11844000. <https://dx.doi.org/10.2305/IUCN.UK.2004.RLTS. T58815A11844000.en>.

Whiles, M.R., K.R. Lips, C.M. Pringle, S.S. Kilham, R.J. Bixby, R. Brenes, S. Connelly, J.C. Colon-Gaud, M. Hunte-Brown, and A.D. Huryn. 2006. The effects of amphibian population declines on the structure and function of Neotropical stream ecosystems. Frontiers in Ecology and the Environment 4: 27-34. 